\title{
Terms of specialized nursing language for people with pressure injury
}

\author{
Termos da linguagem especializada de enfermagem para pessoas com lesão por pressão \\ Términos del lenguaje especializado de enfermería para personas con úlcera por presión
}
Fernando Hiago da Silva Duarte'
ORCID: 0000-0002-2743-0452

Wenysson Noleto dos Santos'

ORCID: 0000-0002-2093-5415

Francisca Simone da Silva'

ORCID: 0000-0003-4506-6225

Dhyanine Morais de Lima'

ORCID: 0000-0002-9723-705X

Sâmara Fontes Fernandes"

ORCID: 0000-0002-2105-0248

Richardson Augusto Rosendo da Silva'

ORCID: 0000-0001-6290-9365

\section{ABSTRACT}

Objective: to validate the terms of the specialized nursing language used in care for hospitalized patients with Pressure Injury, identified in nurses'records, mapping them with the terms of the International Classification for Nursing Practice (ICNP 2017). Methods: methodological study, carried out at a School Hospital in 2018. It was performed: extraction of terms of medical records; normalization; cross-mapping between extracted terms and those in ICNP; ; distribution in the seven axes; theoretical definition and validation of terms. Results: 27,756 terms were extracted. The normalization resulted in 370 relevant terms, being: 225 listed and 145 not listed in the ICNP', being 60 similar, 13 more comprehensive, 38 more restricted and 34 without agreement, all of which are validated.Conclusion : this study identified and validated terms used by nurses to assist people with Pressure Injury. These may contribute to the unification of professional nursing language in care for these clients.

Descriptors: Nursing; Nursing Process; Standardized Terminology in Nursing; Classification; Pressure Ulcer.

\section{RESUMO}

Objetivo: validar os termos da linguagem especializada de enfermagem, utilizada no cuidado às pessoas hospitalizadas com Lesão por Pressão, identificados em registros de enfermeiros, mapeando-os com os termos da Classificação Internacional para a Prática de Enfermagem (CIPE $)$, versão 2017. Métodos: estudo metodológico, realizado em um Hospital Escola, em 2018. Realizou-se: extração dos termos de prontuários; normalização; mapeamento cruzado entre termos extraídos e os constantes na CIPE; ; distribuição destes nos sete eixos; definição teórica e validação dos termos. Resultados: foram extraídos 27.756 termos. A normalização resultou em 370 termos pertinentes, estando: 225 constantes e 145 não constantes na CIPE', sendo 60 similares, 13 mais abrangentes, 38 mais restritos e 34 sem concordância, os quais forma todos validados. Conclusão: o estudo identificou e validou termos utilizados pelos enfermeiros na assistência às pessoas com Lesão por Pressão. Estes poderão contribuir para unificação da linguagem profissional de enfermagem no cuidado a essa clientela.

Descritores: Enfermagem; Processo de Enfermagem; Terminologia Padronizada em Enfermagem; Classificação; Lesão por Pressão.

Silva RAR. Terms of specialized nursing language for people with pressure injury. Rev Bras Enferm. 2019;72(4):1028-35. doi: http://dx.doi.org/10.1590/0034-7167-2018-0492

Corresponding Author:

Richardson Augusto Rosendo da Silva E-mail: rirosendo@yahoo.com.br

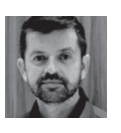

Submission: 06-05-2018 Approval: 09-26-2018

\section{RESUMEN}

Objetivo: validar los términos del lenguaje especializado de enfermería, utilizada en el cuidado a las personas hospitalizadas con Úlcera por Presión, aludiendo a los términos del lenguaje especializado de enfermería utilizado en el cuidado a las personas hospitalizadas con Úlcera por Presión, identificadas en registros de enfermeros, mapeándolos con los términos de la Clasificación Internacional para la Práctica de Enfermería (CIPE)), versión 2017. Métodos: Estudio metodológico, realizado en un hospital escolar en 2018. Se realizó: extracción de los términos de prontuarios; normalización; el mapeo cruzado entre términos extraídos y los constantes en la CIPE; d distribución de estos en los siete ejes; definición teórica y validación de los términos. Resultados: se extrajeron 27.756 términos. La normalización resultó en 370 términos pertinentes, estando: 225 constantes y 145 no constantes en la CIPE', siendo 60 similares, 13 más amplios, 38 más restrictos y 34 sin concordancia, los cuales forma todos validados. Conclusión: el estudio identificó y validó los términos utilizados por los enfermeros en la asistencia a las personas con Úlcera por Presión. Estos podrán contribuir a unificar el lenguaje profesional de Enfermería en el cuidado a esa clientela. Descriptores: Enfermería; Proceso de Enfermería; Terminología Estandarizada en Enfermería; Clasificación; Úlcera por Presión. 


\section{INTRODUCTION}

Pressure Injury (PI) is the result of prolonged pressure on an area of the patient's body, decreasing blood flow, minimizing the distribution of blood, nutrients and oxygen in this area and triggering destruction and tissue death, because the soft tissue is compressed between a bone prominence and a rigid surface over an extended period of time ${ }^{(1)}$.

This can cause additional complications, such as the patient's self-image impairment and self-esteem, as well as causing pain, suffering and constituting a gateway to infection, making it difficult to recover and increasing the length of hospital stay and, consequently, costs for health services ${ }^{(2)}$.

The etiology of the development of $\mathrm{Pl}$ is associated with two determining factors: duration and intensity of pressure. In addition, intrinsic and extrinsic factors are considered to potentiate their evolution. The former are related to advanced age, immobility, nutritional status, anemia, infection, incontinence and skin sensitivity. While the latter refer to shear, moisture, poor hygiene, lack of change of decubitus, use of orthopedic tools, improperly fixed probes, incorrect use of physical and chemical agents, types of mattresses and inadequate seating ${ }^{(1-3)}$.

In this sense, the nurse, as a health professional, has an important role in the knowledge of risk factors, in the use of daily preventive measures and in comprehensive care for people with $\mathrm{Pl}$, developing technical-scientific skills that favor the organization and systematization of care ${ }^{(4)}$, which directly interfere with care provided for users.

Considering the need to systematize nursing care for people with $\mathrm{PI}$, the importance of the use of nursing terminologies is highlighted ${ }^{(5)}$, since they allow the identification and documentation of care standards. The International Classification for Nursing Practice (ICNP ${ }^{\circ}$ ) consists of a standardized terminology of the nursing language ${ }^{(6)}$. Its structure of terms and definitions allows the collection, description and systematic documentation of the elements of nursing practicewhat nurses do (nursing interventions) in relation to certain human needs (nursing diagnoses) to produce results (nursing results)(7).

Thus, nursing records show care provided and represent a vocabulary of the profession, however, when the records are presented incompletely or inaccurately, they can be misinterpreted $^{(8)}$. It consists of a valuable work tool, allowing communication between the health team, tracing parameters to the nursing conducts and evaluation of the clinical evolution of the patient.

Therefore, the termbase allows us to detect concepts that help in the construction of nursing diagnoses, results and interventions, that is, the phenomena that denote the practice of the profession $^{(9)}$. Moreover, it is clear that PI has a high prevalence in general Brazilian hospitals, being considered as an important iatrogeny present in health services, consisting of an indicator for evaluation and monitoring of the quality of health care, implying implications for the practice of clinical nursing ${ }^{(10)}$.

In Brazil, approximately $9 \%$ of all hospitalized patients develop

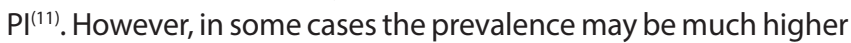
depending on the study population and working conditions. According to Matos et al(12), in the Federal District, some hospitals present PI prevalence of $57.8 \%$ in an Adult ICU; $87.5 \%$ in a Trauma ICU, and $50 \%$ in a General ICU, surpassing the Brazilian average.
In the United States, the prevalence in the hospital network is $14 \%^{(13)}$, while in Portugal it is $37.4 \%^{(12)}$.

Given this panorama, the development and importance of the study is justified, which sought for scientific productions on the termbase of the special language of nursing to care for people hospitalized with PI, without time limit, in the databases/virtual library: Latin American \& Caribbean Literature (LILACS), PubMed, SCOPUS, Cumulative Index to Nursing and Allied Health Literature (CINAHL), Web of Science, Embase, and Cochrane; using the Health Sciences Descriptors (DeCS)/Medical Subject Headings (MeSH): Terminologia/ Terminology; Classificação/Classification; Enfermagem/Nursing.

It was identified, through the findings, that the studies related to the termbase in: children with hospitalized congenital heart diseases; children and adolescents in situations of domestic violence; newborns in the Neonatal Intensive Care Unit (NICU); adults in physical-motor rehabilitation; people in palliative care; ostomized women, elderly women with HIV/AIDS, glimpsing a gap in termbase knowledge of the special nursing language for care for people hospitalized with PI.

In this sense, the research will enable the incorporation of new terms and will subsidize future proposal of registration standardization. This will contribute to the development of ICNP' and the standardized language, as well as the greater visibility of nursing as a science, being able to provide data that support the decision-making process of the nurse, in the managerial, assistance and academic scope in care for people with PI. Consequently, this will influence the technical-scientific improvement of the nursing practice, in order to reduce the high rates of this aggravation in health services and improving care.

With this, the need arose to construct a termbase of the specialized language of nursing for patients with PI from terms extracted from the medical records of people hospitalized with such an injury. In view of the above, the following question arose: what terms of the special nursing language used by nurses when caring for people hospitalized with PI can constitute a database for this area of specialty that guides clinical practice and effective registration of nursing data?

\section{OBJECTIVE}

To validate the terms of the specialized nursing language used in care for people hospitalized with PI, identified in nurses' registers, mapping them to the ICNP' 2017 terms.

\section{METHOD}

\section{Ethical aspects}

The study followed the directives and norms regulating the research involving human beings, established by Resolution 466/2012 of the Brazilian Health Board (Conselho Nacional de Saúde) and was approved by the Research Ethics Committee with Human Beings.

\section{Design, place of study and period}

This is a validation study of content, involving hospitalized patients in the hospitalization units of a School Hospital, in the 
Northeast of Brazil. Data collection took place between January and June 2018.

\section{Population or sample; inclusion and exclusion criteria}

The sample consisted of electronic records of hospitalized patients of both genders, admitted to hospitalization units throughout 2017, and nurses who acted as specialists in the process of validating the terms. The sample consisted of 107 records of people with $\mathrm{PI}$, adopting as inclusion criteria: (I) age over 18 years; (II) to present PI upon admission and/or in the hospitalization process, regardless of the injury stage (III) to have evolution of the registered nurse in the medical record and, as exclusion criterion: (I) patient evolves to death. It is worth noting that, in 2017, a total of 2,540 patients were admitted to this institution, and 112 cases of PI. It is noteworthy that during the collection period, $10 \%$ of the charts that were initially selected did not present the nurses' evolutions or the evolutions were incomplete.

In relation to the nurses involved in the process of validation of the terms, the criteria used for the inclusion of specialists were: (I) to be a nurse; (II) to have at least a Master's degree; (III) publication of an article in a journal, related to PI, terminology, nursing process or nursing classifications. For their identification, a research was carried out by accessing the Lattes Platform (Plataforma Lattes), identifying 136 nurses, for whom invitations were sent electronically, receiving a return of 52 in the first round and 46 in the second round of validation.

\section{Study protocol}

The following steps were developed to achieve the objectives of this study: 1) extraction of terms from the evolution of nurses in medical records; 2) normalization of terms; 3) cross-mapping, where the terms identified in the medical records were compared with the terms present in ICNP'2017; 4) distribution of the terms, not listed in the ICNP', in the structure of the 7-Axis classification; 5) theoretical definition of not listed in the ICNP 2017 terms; 6) validation of the terms identified in the study, including in this process the conceptual definition assigned to them and their respective allocations in one of the 7-Axis ICNP'.

The evolution of the nurses in electronic records was grouped into a single file in Word ${ }^{\circ}$ format, which was converted to the Portable Document Format (PDF). Then, the terms were extracted using a computational tool called "Poronto", which processes information using large-scale ontologies and is widely used in the Health field due to the complexity of its knowledge. It acts from the processing of PDF file, which are transformed into clean and processed text from linguistic notes ${ }^{(14)}$, resulting in a list of terms arranged in order of occurrence, arranged in Excel ${ }^{\circ}$ spreadsheet.

Among the terms extracted, nouns, adjectives and verbs were selected based on the frequency of appearance and relevance to the research theme. Then, the selected terms were submitted to standardization for the standardization of flexion of gender, number and degree of nouns and adjectives, as well as verbal inflections, with the purpose of identifying and removing repetitions of terms, being constantly checked for error rate reduction. This process was carried out by two of the authors of the present study, with one having a Master's degree and another having a Doctoral degree. The selection of terms considered "relevant" occurred by consensus among the group of researchers, based on the authors' clinical experience, considering their performance in care for people with PI. In this sense, we have identified and excluded terms related to medical procedures, pathological processes and medicines. Subsequently, the normalized terms were submitted to the cross-mapping technique, which enabled the cross-referencing of ICNP ${ }^{\circ} 2017$, using Microsoft Office Access $^{\circ} 2010$ software to identify listed and not listed terms in this terminology.

Subsequently, the terms identified in the study were validated using the Delphi technique using two rounds. Included in this process, were the conceptual definitions assigned to them and their respective allocations in one of the 7-Axis ICNP ${ }^{\circ}$. The definition process was carried out by a researcher, through the use of technical dictionaries and Portuguese dictionaries, seeking to construct a meaning based on the literature and systematized according to ICNP' definitions. Next, the opinion of the selected specialist nurses, who acted as judges, was solicited. They expressed the degree of agreement or disagreement with the term, its definition and allocation in the ICNP ${ }^{\circ}$ axes. If it was deemed necessary, the participant had the possibility to register comments or suggestions in a tool field available for it.

\section{Analysis of results, and statistics}

The terms were distributed between the axes "Action", "Client", "Focus", "Judgment", "Location", "Means" and "Time", according to the 7-Axis ICNP" 2017 model, taking into account the congruence of the meaning of the term and the definitions of each axis.

The terms not listed in the ICNP' were subjected to a process of analysis regarding similarity and comprehensiveness in relation to the ICNP' terms, according to the following criteria(10): similar - there is no agreement of spelling, but its meaning is identical to that of the existing term in the ICNP'; more broadly - its meaning is broader than that of the existing term in the ICNP'; more restricted - has a more specific meaning than that of the existing term in ICNP; ; and does not agree - the term is totally different from the ICNP' terms.

In the elaboration of definitions for the terms classified as listed in the ICNP $^{\circ} 2017$, those presented in this classification were used. For those identified as not listed, definitions were assumed in textbooks, nursing and health dictionaries and meanings based on prior knowledge of the authors.

In order to calculate the Concordance Index $(\mathrm{Cl})$ among the judges, a Likert scale was used, considering as concordance the statements " $5=$ Very, very relevant", "4=Very relevant" and " $3=$ Relevant"; and as disagreement the statements " $2=$ Little relevant" and"1=Nothing relevant. $\mathrm{Cl}$ calculation was performed from the formula $\mathrm{Cl}=\mathrm{A} /(\mathrm{ND}+\mathrm{A})$, where $\mathrm{A}$ is the number of agreements and ND is the number of disagreements. The terms that achieved a $\mathrm{Cl} \geq 0.80$ were validated. It should be emphasized that the definitions of the terms that did not reach the $\mathrm{Cl} \geq 0.80$ in the first round were re-elaborated based on the suggestions sent and were sent to a second validation stage, in which consensus was reached among the specialists. 


\section{RESULTS}

27,756 terms were obtained from the medical records of people with PI who met the established criteria. After identifying the terms, they went through normalization, resulting in 370 relevant terms, being 238 nouns, 18 adjectives and 114 verbs. In Chart 1, examples of terms relevant to care for people with PI identified in this study.

Chart 1 - Terms relevant to care for people with Pressure Injury identified in the evolution of nurses, presented by frequency of appearance $(\mathrm{N})$ and categorized by nouns, adjectives and verbs, 2018

\begin{tabular}{|c|c|c|c|c|c|}
\hline Noun & N & Adjective & N & Verb & N \\
\hline Injury & 772 & Partial & 448 & To change & 280 \\
\hline Care & 753 & Complex & 302 & To promote & 158 \\
\hline Patient & 631 & Normal & 347 & To take care & 131 \\
\hline Dressing & 602 & Small & 318 & To perform & 81 \\
\hline Coverage & 585 & Transparent & 267 & To apply & 73 \\
\hline Tissue & 440 & Irregular & 155 & To moisture & 73 \\
\hline Skin & 423 & Regular & 113 & To evaluate & 72 \\
\hline Epithelialization & 238 & Satisfactory & 94 & To observe & 67 \\
\hline Pain & 97 & Mild & 27 & To remove & 57 \\
\hline Inflammation & 94 & Partial & 20 & To monitor & 53 \\
\hline Healing & 38 & Slow & 08 & To recover & 2 \\
\hline
\end{tabular}

The mapping between the 370 relevant terms and the terms in ICNP' 2017 resulted in 225 listed terms and 145 terms not listed. Of these, 60 were identified as similar, 13 were identified as more comprehensive, 38 were classified as more restricted and $34 \mathrm{did}$ not show agreement with the terms of the ICNP'.

As examples of listed terms in ICNP' 2017, identified in the medical records of people with PI: "To follow up", "To apply", "To clean", "To mobilize", “To treat", “To change", “'Discomfort", “Pain", “Edema”, "Fatigue", "Necrosis", "Skin" and "Secretion". Examples of terms not listed and included in the ICNP² 2017:"Abscess";"Aseptic";"Caution"; "Circulation";" Shearing";"Tissue healing";"Bedsore";" "General state"; "Epithelialization"; Exudate".

Chart 2 presents examples of terms not listed in the ICNP 2017, which have been classified as similar terms, broader terms, and more restricted terms.

Chart 2 - Terms of the nursing language for persons with Pressure Injury not listed in the ICNP", classified as similar, more comprehensive and more restricted than the ICNP' 2017 terms

\begin{tabular}{|c|c|c|}
\hline Term identified & $\begin{array}{c}\text { Corresponding term } \\
\text { of the ICNP }\end{array}$ & $\begin{array}{c}\text { Analysis of the term } \\
\text { identified }\end{array}$ \\
\hline To perform & To carry out & Similar \\
\hline To help & To help & Similar \\
\hline To admit & Admission & Similar \\
\hline Odor & Fetid odor & More comprehensive \\
\hline Image & Body image & More comprehensive \\
\hline Disease & Disease Incidence & More comprehensive \\
\hline Air mattress & Feather mattress & More restricted \\
\hline Shoulder Joint & Articulation & More restricted \\
\hline Dehydrated skin & Skin & More restricted \\
\hline
\end{tabular}

Chart 3 demonstrates the terms of the special nursing language for people with PI not included in the ICNP' 2017, validated by the second classification axes.

The definitions of 145 terms that did not reach the $\mathrm{Cl} \geq 0.80$, in the first round, were re-elaborated based on the suggestions sent by the experts and sent to a second stage, obtaining the consensus. At the end of the process, all 145 terms were validated.

In relation to the "Focus" axis, the terms"epithelialization","devitalized tissue" and "patient safety" required a new round between the specialists for their validations, both in relation to the definitions and in relation to the axis where were allocated. In the "Judgment" axis, two terms, "stable" and "resected", required a second round for validation with respect only to the axis. In the "Action", "Location" and "Time" axes, all the proposed terms were validated in the first stage of the validation process, both in relation to the definitions and in relation to the axis in which they were allocated. In the "Means" axis, the definitions of the terms "clean technique" and "multidrug resistant microorganism" were validated in the second round, after being modified by the experts'. In the "Client" axis, the term "friend" had to be reworked according to the experts'suggestions and validated in the second stage of the process.

Chart 3 - Terms of the special nursing language for people with Pressure Injury not listed in the ICNP'2017, validated according to classification axes

\begin{tabular}{|c|c|}
\hline $\begin{array}{l}\text { Focus } \\
\text { (56 terms) }\end{array}$ & $\begin{array}{l}\text { Abscess; Aversion; Aseptic; Self-rejection; Aspect; Attrition } \\
\text { area; Abnormality; Apathy; Asthenia; Smell; Caution; Circu- } \\
\text { lation; Shear; Tissue healing; Dislocation; Disease; Bedsore; } \\
\text { Emotional state; General state; Staging; Epithelization; } \\
\text { Choice; Effort; Eupneia; Exudate; Friction; Flaccid; Fragility; } \\
\text { Groan; Inspection; Image; Immobility; Ischemia; Change; } \\
\text { Note; Oxygenation; Odor; Thin skin; Dehydrated skin; Non- } \\
\text { intact skin; Protrusion; Protection; Healing process; Pus- } \\
\text { tules; Complaint; Retraction; Signs of inflammation; Patient } \\
\text { safety; Granulation tissue; Devitalized tissue; Macerated tis- } \\
\text { sue; Necrotic tissue; Turgor; Moisture;Vesicle;Vulnerability. }\end{array}$ \\
\hline $\begin{array}{l}\text { Judgment } \\
\text { (11 terms) }\end{array}$ & $\begin{array}{l}\text { Calm; Characteristic; Stable; Hydrated; Unstable; Irregular; } \\
\text { Same level; Reduced; Resected; Satisfactory; Transparent. }\end{array}$ \\
\hline $\begin{array}{l}\text { Action } \\
\text { ( } 27 \text { terms) }\end{array}$ & $\begin{array}{l}\text { To help; To admit; To schedule; To continue; To take care; To de- } \\
\text { bride; To degerm;To wander; To estimate;To evolve;To hydrate; } \\
\text { To indicate; To modify; To provide; To perform; To receive; To } \\
\text { prescribe; To recognize; To recede; To renew; To follow; To add; } \\
\text { To request; To use; To moist; To check; To make it viable. }\end{array}$ \\
\hline $\begin{array}{l}\text { Location } \\
\text { (17 terms) }\end{array}$ & $\begin{array}{l}\text { Armpit; Shoulder joint; Iliac crest; Elbow; Epidermis; Inter- } \\
\text { gluteal; Lateral malleolus; Medial malleolus; Lower mem- } \\
\text { bers; Upper limbs; Calf; Scapular region; Sacral; Subclavian; } \\
\text { Trochanteric; Granulation Tissue; Necrosed Tissue. }\end{array}$ \\
\hline $\begin{array}{l}\text { Means } \\
\text { (25 terms) }\end{array}$ & $\begin{array}{l}\text { Dressing; Anti-inflammatory; Calcium alginate; Moistur- } \\
\text { izing cream; Collagenase; Air mattress; Degerming solu- } \\
\text { tion; Debridement; Intravenous; Enteral; Plaster; Team of } \\
\text { dressings; Crape band; Polyurethane film; Hypoallergenic } \\
\text { adhesive tape; Gastrostomy; Gazes; Hydrocolloid; Massage; } \\
\text { Micropore; Sunflower oil; Research of multidrug resistant } \\
\text { microorganism; Saline; Swab; Clean technique. }\end{array}$ \\
\hline $\begin{array}{l}\text { Time } \\
\text { (6 terms) }\end{array}$ & Weekend; Hour; Schedule; Morning; Nocturnal; Evening. \\
\hline $\begin{array}{l}\text { Client } \\
\text { (3 terms) }\end{array}$ & Friend; Husband; Son. \\
\hline
\end{tabular}

\section{DISCUSSION}

In this study, terms related to PI were identified. This has replaced the previous terms, among them "bedsore", "decubitus ulcer", 
"compression ulcer", "pressure ulcer", since there was a change in the terminology of this complaint by the National Pressure Ulcer Advisory Panel (NPUAP), since it considers that the term "Pressure Injury" is more precise ${ }^{(1)}$. However, in nursing practice, these terms are still often used synonymously, disregarding their differences in characterization, nomenclature or hierarchy.

In nursing, terminology has an important role, due to its direct participation in the development in care practice, as its use provides improvements in the registries through standardizations of the language and terms. It is used as a communication within a certain field of knowledge, enabling the development of a specific vocabulary of the area and, thus, reducing ambiguity. In the ICNP ${ }^{\circ} 2017$, the term "injury" is present in the "focus" axis and is defined as trauma ${ }^{(6)}$.

Currently, nursing develops several strategies for standardization and formulation of its own terminology, allowing the identification, naming and classification of concepts that will be used in computer systems, teaching strategies and training of professionals and field of knowledge of the field ${ }^{(8)}$. Besides conferring an advance to the practice in health, it facilitates the communication between the multidisciplinary team, which would be guided by well-established and standardized concepts, minimizing the risks of ambiguity in the understanding, which are related to the practical and individual experience of the professional.

$\mathrm{Pl}$ is characterized as one of the main skin problems in hospitalized patients, especially those with critical clinical conditions. The hospital environment can trigger several risks to the health of the patients, conditioning them to the worsening of their clinical situation or hindering the recovery ${ }^{(15)}$.

The onset of $\mathrm{PI}$ is the result of prolonged pressure on an area of the patient's body, decreasing blood flow, minimizing the distribution of blood, nutrients and oxygen in this area and triggering tissue destruction and death as the soft tissue is compressed between a prominence bone and a hard surface over an extended period of time ${ }^{(2-4)}$.

Despite the advances in hard technologies that minimize or tend to prevent or mitigate $\mathrm{Pl}$, a high incidence of these injuries was detected. The study highlights incidence of 23.1 to $59.5 \%$, especially in patients admitted to Intensive Care Units (ICU), given that in this setting, the appearance of PI is associated as one of the main skin related iatrogenies ${ }^{(2)}$.

Being directly related to nursing practice, since this professional category is closer to the patient and assumes responsibilities with it, such as, for example, change of decubitus is considered one of the main risk factors for the development of PI. Therefore, the appearance of such injuries indicates a "failure" in the preventive action of nursing and, therefore, it is considered as an important iatrogeny and indicator of quality of a health service and/or care.

On the other hand, the terms "oxygenation", "tissue perfusion"; "Restlessness"; "Discomfort" belonging to the "focus" axis, are directly related to $\mathrm{Pl}$. Oxygen consumption and oxidation phenomena of vital activities have a direct and immediate relation with vital functions, and together with the circulatory system, they facilitate the transport of oxygen. This is conducted to the other cells, acting in the process of cellular respiration ${ }^{(16)}$.

In the case of reduced mobility, these factors associated with the pressure of bony prominences and the prolonged time, reduces the distribution of blood in the integumentary tissue and, consequently, occurs a reduction of the oxygen distribution, reducing the cellular work and contributing to the formation of injuries ${ }^{(17)}$. In this context, it is up to the nurse to verify signs of hypoxemia and to establish strategies in order to revert this phenomenon through devices capable of providing supplemental oxygen, these being nasal catheters or Venturi masks with varied fractions, depending on the needs of the patient ${ }^{(4)}$. This indicates, once again, the importance of nursing performance in the identification of signs of risk to PI.

Corroborating with the terminologies associated with PT, the terms "water"; "to hydrate"; "to install" present in the axis "focus", have direct relation with the process of hydration. It can be promoted at enteral level, providing water or liquids via oral, as well as crystalloid solutions via parenteral ${ }^{(17)}$. In the context of interventions for the prevention of these injuries, solutions that hydrate the skin of the individual, such as, for example, moisturizing creams that avoid the dryness of the epidermis are used, being this a factor for the development of $\mathrm{PI}^{(18)}$.

It is necessary to establish strategies with the nursing teams in the context of hydration of the skin, to inquire and inspect the skin daily, to apply topical moisturizers, to keep the skin clean and dry, to examine the skin turgor, analyzing signs of dehydration or hypervolemia associated with edemas, to keep the skin hydrated (avoid rubbing bony prominences in hyperemic areas and with reduced sensitivity) ${ }^{(15)}$. In this way, it must act in the control of the humidity, with the objective of keeping the skin dry and moisturized with creams based on essential fatty acids or urea, in case of dry skin ${ }^{(16)}$.

The terms "appetite", "malnutrition", "food intake" and "gastric tube" are linked to the patient with these injuries, as the nutritional status of the injury should be evaluated by the nursing team in conjunction with other health professionals, since nutritional changes have a direct impact on the development of PI, especially in overweight patients ${ }^{(19)}$.

Another factor of extreme relevance in care for people with PI relates to the monitoring of nutritional status due to its correlations with nutrient distribution and elements, such as vitamins and proteins required in cellular functioning and in the process of building, rebuilding and repairing tissues ${ }^{(17)}$. In this sense, the nurse must monitor the nutritional status by observing the acceptance of the diet provided, when orally; adaptation of enteral diets; besides the follow-up of laboratory tests.

Parallel to the evaluation of the nutritional status of people with PI, eliminations, mainly vesical and intestinal, and also fluids excreted via enteral, cutaneous, or facilitated by drains and hospital devices. The terms "constipation"; "diarrhea"; "edema"; "urination"; "urinary catheter"; "Gastric substance", linked to physiological eliminations, need to be evaluated and their characteristics observed so that necessary interventions are established in the prevention and treatment of the injuries ${ }^{(19)}$.

Patient, when restricted to the bed, with reduced mobility, difficulty in controlling the sphincters, with bladder or intestinal incontinence, needs devices to catch the excreta; be minimally invasive, with the use of diapers, or totally invasive, with bladder catheters. Thus, it is up to the nurse to confer such needs of these patients and to construct strategies capable of minimizing the contact of these bodily fluids with the skin ${ }^{(20)}$. 
In addition to the terms already expressed, the terms "dependency" were identified; "immobility"; "reduced" and "restricted", related to the contexts of the patient with reduced mobility or old age. They undergo forces such as attrition, pressure, shear and friction, being related to the development of PI. Reduced mobility is pointed out in the literature as one of the main extrinsic factors that contribute to the development of these injuries due to poor tissue perfusion, reducing tissue tolerance to pressure on bone prominence, promoting cell death and tissue necrosis ${ }^{(2)}$. Thus, actions, such as body hygiene, dry skin maintenance, change of decubitus and perineal hygiene, after elimination and feeding, are essential for PI prevention ${ }^{(18,21)}$.

The verbs identified and expressed in this study portray the predominant and necessary nursing actions related to nursing care for people with PI as: "to apply", "to evaluate", "to follow up", "to care for", "to debride", "to degerm", "to evolve", "to indicate", "to observe", "to prescribe", "to renew"; "to treat", "to change", "to measure", "to plan", "to monitor", "to change", "to register", "to moisten". These reinforce the importance of the use of standardized nursing terminologies in care for these clients.

Studies indicate that high rates of $\mathrm{PI}$, especially in populations at risk, represent a challenge for health professionals in the implementation of preventive actions and use of technological advances for treatment ${ }^{(17-22)}$. Among the technological resources for treatment, there are different types of coverage, which should be indicated according to the following objectives: eliminate non-viable tissue; minimize the risk of infection; to meet the characteristics of the injury; to meet patient and family's therapy goals; and have a good cost / benefit ratio. Thus, adequate choice of coverage benefits the healing process in the medium and long term, depending on the staging based on the degree of tissue destruction of injuries and conditions of the patient ${ }^{(22)}$.

The author points out that the nurse has autonomy and freedom to outline care strategies to be adopted in the treatment of $\mathrm{Pl}$, which includes evaluation of the injury and skin of users as a whole, followed by planning, implantation, evolution and nursing registration ${ }^{(23)}$. In addition, nurse care should be differentiated in order to meet the specific needs of users and may be qualified as preventive when presenting the diagnosis of impaired skin integrity or care when impaired skin integrity is already present ${ }^{(24)}$.

Authors point out that the premature discovery of $\mathrm{PI}$ and risky conditions, such as dry and brittle skin, the presence of erythema, maceration, fragility, high temperature or hardening, are essential during nursing care ${ }^{(25-26)}$. However, at the time the injury formation process is already lodged, certain care must be taken into account as: assessment of the injury as to its nature, shape and location, type of tissue, exudate and odor present; measurement of its extension; examination of the skin around the injury for the presence of edema, hyperemia, hyperthermia and pain; besides the dressing performance according to the characteristics of $\mathrm{PI}^{(27)}$.

The ICNP ${ }^{\circ}$ use as a reference terminology, in this research, allowed the cross-mapping of terms identified in care for patients with PI, with the terms of their classification. This demonstrates that it is possible to use this Classification in assisting this clientele, since ICNP ${ }^{\circ}$ was developed to congregate the existing vocabularies, to develop new vocabularies that allow the systematic documentation of nursing activities, using standardized nursing diagnoses, results and interventions.

The Termbase construction is important so that nursing recognizes its own language of the professional practice, as well as to standardize this language. This base will allow the composition of the statements of diagnosis, results and nursing interventions in care for people with PI, reaffirming that the nursing team is a vital tool in the prevention of PI as well as in its treatment, since when the injury is installed, the nursing professional, specifically the nurse, is responsible for its continuous care and evaluation. Through his registrations, the nurse shares with the other team members the patient's clinical situation, serving as an evaluation parameter.

Therefore, the use of standard terms throughout the team suggests a uniformity in the assistance, since all professionals will be communicating with the same theoretical-technicalscientific basis, reducing the risks of communication failure and, consequently, technical errors.

\section{Study limitations}

It should be pointed out that, because the search for terms was restricted to only one health institution, the present study may not reveal the complexity of care for people with $\mathrm{Pl}$, which is a limitation. Another limitation concerns the possibility of meeting, in part, the criteria of ISO 12300/2006 in cross-mapping.

\section{Contributions to the Nursing area}

This study can contribute to terminologies development and nursing language standardization, in the context of care for people with $\mathrm{PI}$, which may support the documentation and, consequently, reflect on the visibility of the profession. Thus, the terms identified in the present study could be used to compose nursing diagnoses, results and interventions for this clientele.

\section{CONCLUSION}

There was a higher frequency of terms classified and listed in the ICNP ${ }^{\circ} 2017$, which ensures the credibility of this terminology, being a terminological tool that should be included in information systems and records of clinical practice in the national and world setting, corroborating with the scientific and technological development of the nursing field. In addition, there were identified terms that are not represented in this classification system, making it necessary to constantly update the ICNP'. It should be emphasized that all terms not listed in the ICNP ${ }^{\circ}$ identified in this study were validated for the content.

There was a prevalence of terms in the "focus", "action" and "means" axis, and less frequently, the terms "location", "judgment", "time" and "client". The terms of the "focus" axis demonstrated the relevant factors in the prevention and treatment of PI. Next, the "action" axis demonstrated terms capable of constructing nursing interventions capable of minimizing the risks inherent to the hospitalization process of these patients. The "means" axis grouped terms that signalized methods of how to perform the nursing interventions to people with PI. The "location" axis concentrated terms related to the anatomical structures of people 
Terms of specialized nursing language for people with pressure injury Duarte FHS, Santos WN, Silva FS, Lima DM, Fernandes SF, Silva RAR.

with PI. The "judgment" axis demonstrated the clinical opinion or determination related to the focus of nursing practice during care for this clientele. The "time" axis presented terms related to the period of time in which the nursing actions were performed. The "client" axis demonstrated the subjects who received care.
Finally, the research allowed to explore and to know the terms used by nurses in care provided for people hospitalized with $\mathrm{PI}$, enabling the development of diagnosis/results statements and nursing interventions and also the unification of the nurse's professional language.

\section{REFERENCES}

1. National Pressure Ulcer Advisory Panel, European Pressure Ulcer Advisory Panel-NPUAP. Prevention and treatment of pressure ulcers: quick reference guide. Emily Haesler (Ed.). Cambridge Media: Osborne Park [Internet]. 2016 [cited 2018 Feb 10]. Available from: http://www. npuap.org/resources/educational-and-clinical-resources/pressure-injury-staging-illustrations/

2. Karahan A, Abasoglu A, Isik SA, Cevik B, Saltan C, Elbas NO, Yalili A. Factors affecting wound healing in individuals with pressure ulcers: a retrospective study. Ostomy Wound Manage [Internet]. 2018 [cited 2018 Jun 8];64(2):32-9.Available from: https://www.ncbi.nlm.nih.gov/pubmed/29481325

3. Koivunen M, Hjerppe A, Luotola E, Kauko T, Asikainen P. Risks and prevalence of pressure ulcers among patients in an acute hospital in Finland. J Wound Care [Internet]. 2018 [cited 2018 Jun 8];27(Sup2):S4-S10. Available from: https://www.ncbi.nlm.nih.gov/pubmed/29419369

4. Nuru N, Zewdu F, Amsalu S, Mehretie Y. Knowledge and practice of nurses towards prevention of pressure ulcer and associated factors in Gondar University Hospital, Northwest Ethiopia. BMC Nurs [Internet]. 2015 [cited 2018 Jun 8];16;14:34. Available from: https://www.ncbi. nlm.nih.gov/pubmed/26034398

5. Caballero E, Aguilar N, Alegría M, Díaz I, Chacón C, Hernández A, et al. Nivel de uso del linguaje estandarizado en el proceso de enfermería. Enferm: Cuid Hum [Internet]. 2015 [cited 2015 Nov 26];4(1):39-45. Available from: https://doi.org/10.22235/ech.v4i1.530

6. Garcia TR. (Org.). Classificação internacional para prática de enfermagem (CIPE ${ }^{\circledast}$ ): versão 2017. Porto Alegre: Artmed; 2017.

7. Garcia TR. ICNP ${ }^{-}$: a standardized terminology to describe professional nursing practice. Rev esc Enferm USP [Internet]. 2016 [cited 2018 Feb 01];50(3):376-81. Available from: http://www.scielo.br/pdf/reeusp/v50n3/0080-6234-reeusp-50-03-0376.pdf

8. Carvalho CMG, Cubas MR, Nóbrega MML. Brazilian method for the development terminological subsets of ICNP®: limits and potentialities. Rev Bras Enferm [Internet]. 2017 [cited 2018 Feb 01];70(2):430-5. Available from: http://www.scielo.br/pdf/reben/v70n2/0034-7167reben-70-02-0430.pdf

9. Gomes DC, Cubas MR, Pleis LE, Shmeil MAH, Peluci APVD. Termos utilizados por enfermeiros em registros de evolução do paciente. Rev. Gaúcha Enferm. [Internet]. 2016 [cited 2018 Jun 05];37(1):e53927. Available from: http://www.scielo.br/pdf/rgenf/v37n1/en_0102-6933rgenf-1983-144720160153927.pdf

10. Melleiro MM, Tronchin DMR, Baptista CMC, Braga AT, Paulino A, Kurcgant P. Indicadores de prevalência de úlcera por pressão e incidência de queda de paciente em hospitais de ensino do município de São Paulo. Rev Esc Enferm USP [Internet]. 2015 [cited 2018 Jun 05];49(2):55-9. Available from: http://www.scielo.br/pdf/reeusp/v49nspe2/1980-220X-reeusp-49-spe2-0055.pdf

11. Souza NR, Freire DA, Souza MAO, Santos ICRV, Santos LV, Bushatsky M. Fatores predisponentes para o desenvolvimento da lesão por pressão em pacientes idosos: uma revisão integrativa. Rev Estima [Internet]. 2017 [cited 2018 Jun 05];15(4). Available from: https://www. revistaestima.com.br/index.php/estima/article/view/442

12. Matos LS, Duarte NLV, Minetto RC. Incidência e prevalência de úlcera por pressão no CTI de um Hospital Público do DF. Rev Eletrôn Enferm[Internet]. 2010[cited 2018 Jun 05];12(4):719-26. Available from: https://www.revistas.ufg.br/fen/article/view/8481

13. Blanes L, Duarte IDS, Calil JA, Ferreira LM. Avaliação clínica e epidemiológica das úlceras por pressão em pacientes internados no Hospital São Paulo. Rev Assoc Med Bras [Internet]. 2004 [cited 2018 Jun 05];50(2):182-7. Available from: http://www.scielo.br/pdf/\%0D/ramb/v50n2/20781.pdf

14. Zahra FM, Carvalho DR, Malucelli A. Poronto: ferramenta para construção semi automática de ontologias em português. J Health Inform [Internet]. 2013[cited 2018 Jun 05];5(2). Available from: http://www.jhi-sbis.saude.ws/ojs-jhi/index.php/jhi-sbis/article/view/232

15. Tirgari B, Mirshekari L, Forouzi MA. Pressure injury prevention: knowledge and attitudes of Iranian intensive care nurses. Adv Skin Wound Care [Internet]. 2018 [cited 2018 Feb 02];31(4):1-8. Available from: https://www.ncbi.nlm.nih.gov/pubmed/29561349

16. Kayser SA, VanGilder CA, Ayello EA, Lachenbruch C. Prevalence and analysis of medical device-related pressure injuries: results from the international pressure ulcer prevalence survey. Adv Skin Wound Care [Internet].2018 [cited 2018 Feb 02];31(6):276-85. Available from: https://www.ncbi.nlm.nih.gov/pubmed/29782417

17. Odgaard L, Aadal L, Eskildsen M, Poulsen I. Nursing sensitive outcomes after severe traumatic brain injury: a nationwide study. J Neurosci Nurs [Internet]. 2018 [cited 2018 Feb 02];50(3):149-54. Available from: https://www.ncbi.nlm.nih.gov/pubmed/29652735

18. Wu-Fienberg Y, Henzel MK, Richmond MA, Becker DB. Impact of interdisciplinary rounds in the spinal cord injury unit on relational coordination for patients with pressure injury: a pilot study. J Spinal Cord Med [Internet]. 2018 [cited 2018 Feb 02];6:1-6. Available from: https://www.ncbi.nlm.nih.gov/pubmed/29509096

19. Kasikçi M, Aksoy M, Ay E. Investigation of the prevalence of pressure ulcers and patient-related risk factors in hospitals in the province of Erzurum: a cross-sectional study. J Tissue Viability[Internet]. 2018 [cited 2018 Jun 02];S0965-206X(17)30121-3. Available from: https://www. ncbi.nlm.nih.gov/pubmed/29776817 
20. Bernardes RM, Caliri MHL. Pressure ulcer prevalence in emergency hospitals: a cross-sectional study. Online Braz J Nurs [Internet]. 2016 [cited 2018 Jun 8];15(2):236-44. Available from: http://www. Objnursing.uff.br/index.php/nursing/article/view/5391/pdf_1

21. Martin D, Albensi L, Van Haute S, Froese M, Montgomery M, Lam M, et al. Healthy Skin Wins: a glowing pressure ulcer prevention program that can guide evidence-based practice. Worldviews Evid Based Nurs [Internet]. 2017 [cited 2018 Jun 8];1-11. Available from: http:// onlinelibrary.wiley.com/doi/10.1111/wvn.12242/epdf

22. Palagi S, Severo IM, Menegon DB, Lucena AF. Laser therapy in pressure ulcers: evaluation by the Pressure Ulcer Scale for Healing and Nursing Outcomes Classification. Rev Esc Enferm USP [Internet]. 2015 [cited 2018 Jun 8]; 49(5):820-6. Available from: http://www.scielo.br/ $\mathrm{pdf} /$ reeusp/v49n5/0080-6234-reeusp-49-05-0826.pdf

23. Rowe AD, McCarty K, Huett A. Implementation of a nurse driven pathway to reduce incidence of hospital acquired pressure injuries in the pediatric intensive care setting. J Pediatr Nurs [Internet]. 2018 [cited 2018 Jun 8]; S0882-5963(17)30483-9. Available from: https://www.ncbi. nlm.nih.gov/pubmed/29548602

24. Barakat-Johnson M, Barnett C, Wand T, White K. Knowledge and attitudes of nurses toward pressure injury prevention: a cross-sectional multisite study. J Wound Ostomy Continence Nurs [Internet]. 2018 [cited 2018 Jun 8];45(3):233-7. Available from: https://www.ncbi.nlm. nih.gov/pubmed/29722753

25. Etafa W, Argaw Z, Gemechu E, Melese B. Nurses' attitude and perceived barriers to pressure ulcer prevention. BMC Nurs [Internet]. 2018 [cited 2018 Jun 8];16;17:14. Available from: https://www.ncbi.nlm.nih.gov/pubmed/29686535

26. Barrois B, Colin D, Allaert FA. Prevalence, characteristics and risk factors of pressure ulcers in public and private hospitals care units and nursing homes in France. Hosp Pract (1995) [Internet]. 2018 [cited 2018 Jun 8];46(1):30-6. Available from: https://www.ncbi.nlm.nih.gov/pubmed/29241381

27. Van Leen M, Halfens R, Schols J. Preventive effect of a microclimate-regulating system on pressure ulcer development: a prospective, randomized controlled trial in Dutch nursing homes. Adv Skin Wound Care[Internet]. 2018 [cited 2018 Jun 8];31(1):1-5. Available from: https://www.ncbi.nlm.nih.gov/pubmed/29240594 